\title{
Biosynthesis of Silver Nanoparticles by Conyza canadensis and Their Antifungal Activity against Bipolaris maydis
}

\author{
Yueming $\mathrm{Yi}^{1,{ }^{\dagger}}$, Changjin Wang ${ }^{1,+}$, Xinxin Cheng ${ }^{1}$, Kechuan $\mathrm{Yi}^{2}$, Weidong Huang ${ }^{1, *}$ and Haibing Yu ${ }^{1, *}$ \\ 1 College of Agriculture, Anhui Science and Technology University, Chuzhou 233100, China; \\ Yiym@ahstu.edu.cn (Y.Y.); wangcj@ahstu.edu.cn (C.W.); chengxx@ahstu.edu.cn (X.C.) \\ 2 College of Mechanical Engineering, Anhui Science and Technology University, Chuzhou 233100, China; \\ Yikc@ahstu.edu.cn \\ * Correspondence: huangwd@ahstu.edu.cn (W.H.); yuhb@ahstu.edu.cn (H.Y.) \\ + These authors contribute equally.
}

check for updates

Citation: Yi, Y.; Wang, C.; Cheng, X.; Yi, K.; Huang, W.; Yu, H. Biosynthesis of Silver Nanoparticles by Conyza canadensis and Their Antifungal Activity against Bipolaris maydis. Crystals 2021, 11, 1443. https:// doi.org/10.3390/cryst11121443

Academic Editors: Witold Łojkowski, Yufeng Guo, Shuai Wang, Mao Chen, Kexin Jiao, Lingzhi Yang, Feng Chen and Fuqiang Zheng

Received: 22 October 2021

Accepted: 22 November 2021

Published: 23 November 2021

Publisher's Note: MDPI stays neutral with regard to jurisdictional claims in published maps and institutional affiliations.

Copyright: (c) 2021 by the authors. Licensee MDPI, Basel, Switzerland. This article is an open access article distributed under the terms and conditions of the Creative Commons Attribution (CC BY) license (https:/ / creativecommons.org/licenses/by/ $4.0 /$ )

\begin{abstract}
Silver nanoparticles were biosynthesized from Conyza canadensis leaf extract with the help of a microwave oven. The UV-vis spectrum showed the maximum absorption at $441 \mathrm{~nm}$, corresponding to the surface plasmon resonance of silver nanoparticles. Transmission electron microscope and scanning electron microscope images showed that the synthesized silver nanoparticles were spherical or near-spherical with an average diameter of $43.9 \mathrm{~nm}$. X-ray diffraction demonstrated nanoparticles with a single-phase cubic structure. As-synthesized silver nanoparticles displayed prominent antifungal activity against Bipolaris maydis. The colony inhibition rate reached $88.6 \%$ when the concentration of nanosilver colloid was $100 \mu \mathrm{L} \cdot \mathrm{mL}^{-1}(v / v)$. At such a concentration, no colony formation was observed on the solid plate. The diameter of the inhibition zone was $13.20 \pm 1.12 \mathrm{~mm}$. These results lay the foundation for the comprehensive control of plant pathogens using an environmentally friendly approach.
\end{abstract}

Keywords: antimicrobial activity; silver nanoparticles; Conyza canadensis; Bipolaris maydis

\section{Introduction}

The use of nanotechnology, which appeared later than bio-engineering, has expanded in the last few decades [1-3]. It makes traditional substances into nanoscale materials, which display excellent performance, including optical, magnetic, physical, and chemical characteristics, compared with their bulk counterparts [4-6]. Among these materials, silver nanoparticles have proved to be one of the most important types. Consequently, significant research has been conducted on the synthesis, characterization, and application of silver nanoparticles [7-14].

Silver was used to disinfect and dress wounds in ancient times; its antimicrobial property has drawn much attention since then. Silver nanoparticles improve the antimicrobial activity of silver and have proven to be efficient. They inhibit bacteria, fungi, and viruses. Silver nanoparticles synthesized using the chemical approach exhibited an excellent antibacterial effect against Staphylococcus aureus (ATCC 6538p) at $50 \mu \mathrm{g} \cdot \mathrm{mL}^{-1}$; the bacteria cells, enzymatic activity, and proteins changed [15]. The minimum bactericidal concentration of silver nanoparticles synthesized by Descurainia sophia against Agrobacterium tumefaciens (strain GV3850) and A. rhizogenes (strain 15843) was 4 and $8 \mu \mathrm{g} . \mathrm{mL}^{-1}$, respectively [16]. The silver nanoparticles synthesized by Phoenix dactylifera showed a significant inhibitory effect on Rhizoctonia solani (AG2_2) cultures; the concentration of $25 \mu \mathrm{g} / \mathrm{mL}$ prevented approximately $83 \%$ of the mycelium growth of the fungus [17]. Silver nanoparticles synthesized using turnip leaf extract interacted with several wood-degrading fungal pathogens, such as Gloeophyllum abietinum, Gloeophyllum trabeum, Chaetomium globosum, and Phanerochaete sordida. The result showed cellulose and lignocellulose degradation for all of the tested fungi [18]. The in vitro anti-HBV (Hepatitis B Virus) activities of silver nanoparticles (about 
10 and $50 \mathrm{~nm}$ ) were determined using the HepAD38 cell line. The results showed that silver nanoparticles could inhibit the in vitro production of HBV RNA and extracellular virions [19]. The anti-HIV (Human Immunodeficiency Virus) activity of silver nanoparticles was proven in the early stage of viral replication and post-entry stages of its life cycle; the results made it possible to inhibit a wide variety of circulating HIV-1 strains [20].

In this study, the silver nanoparticles biosynthesized from Conyza canadensis extract were applied to determine their antifungal activity against Bipolaris maydis. Fungicides have made an undeniable contribution to disease control. However, in the current scenario, several drawbacks became apparent, such as pesticide residue, environmental pollution, pathogens resistance, and so forth. It is necessary to explore neotype and stable fungistats to replace or assist fungicides. As non-antibiotic agents, silver nanoparticles could overcome such problems to the greatest degree.

\section{Materials and Methods}

\subsection{Fungus Isolation and Plant Tissue}

The single-spore isolate of $B$. maydis was preserved in the Laboratory of Plant Protection at Anhui Science and Technology University. C. Canadensis was gathered from the plantation of the same campus.

\subsection{Biosynthesis of Silver Nanoparticles}

Air-dried C. Canadensis leaves were cut into tiny pieces $(1 \mathrm{~cm} \times 1 \mathrm{~cm})$ after washing them thoroughly with distilled water. About $10 \mathrm{~g}$ of leaves was added to $100 \mathrm{~mL}$ of deionized water and heated in a microwave oven at $800 \mathrm{~W}$ for $10 \mathrm{~min} . \mathrm{AgNO}_{3}$ solution $\left(100 \mathrm{mmol} \cdot \mathrm{L}^{-1}\right)$ was freshly prepared as stock solution. The leaf extract was filtered with Whatman No.1 paper. After that, $1 \mathrm{~mL}$ leaf filtrate and $1 \mathrm{~mL} \mathrm{AgNO}_{3}$ stock solution were added to $98 \mathrm{~mL}$ deionized water, making the final concentration of $\mathrm{AgNO}_{3} 1 \mathrm{mmol} \cdot \mathrm{L}^{-1}$. Finally, the mixture was put into a microwave oven and heated at $800 \mathrm{~W}$ for $2 \mathrm{~min}$. The color and UV-vis spectrum of the solution were measured.

\subsection{Characterization of Silver Nanoparticles}

Several analysis tools, such as a UV-vis absorption spectrometer, transmission electron microscope (TEM), scanning electron microscope (SEM), and X-ray powder diffractometer (XRD), and energy-dispersive X-ray spectroscopy (EDX) were applied to determine the maximum absorption peak, morphology, crystal structure, particle size, and size distribution so as to obtain the detailed information of synthesized silver nanoparticles.

\subsection{Antifungal Activity of Silver Nanoparticles against B. maydis}

\subsubsection{Inhibition of Colony Growth}

Different volumes $(1,2,3,4$, and $5 \mathrm{~mL})$ of nanosilver colloid and varied volumes $(4,3,2,1$, and $0 \mathrm{~mL})$ of sterile water were added to $45 \mathrm{~mL}$ melted PDA (Potato dextrose agar) separately, and the concentration of nanosilver colloid was set as 20,40,60,80, and $100 \mu \mathrm{L} \cdot \mathrm{mL}^{-1}(v / v)$, respectively. The control contained $45 \mathrm{~mL}$ melted PDA medium and $5 \mathrm{~mL}$ sterile water. Fungus blocks $(\varphi=5 \mathrm{~mm})$ were drilled from cultivated B. maydis, and one specimen was placed in the center of each Petri dish, then inoculated, followed by incubation at $28^{\circ} \mathrm{C}$ for $3-5$ days. Each control and treatment was performed in three replicates. The inhibition rate of silver nanoparticles against $B$. maydis was calculated using the following equation.

Inhibition rate $=[($ Diameter of control colony - Diameter of treatment colony $) /($ Diameter of control colony - Diameter of fungus block $)] \times 100 \%$

\subsubsection{Influence on Colony Formation}

The PDA plates contained different concentrations $\left(20,40,60,80\right.$, and $100 \mu \mathrm{L} \cdot \mathrm{mL}^{-1}$, $v / v)$ of nanosilver colloids, respectively. About $45 \mathrm{~mL}$ melted PDA medium with $5 \mathrm{~mL}$ sterile water was set as control. The spores' suspension of the B. maydis isolate was adjusted to $10^{6} \mathrm{~mL}^{-1}$ with a counting chamber. Then, $100 \mu \mathrm{L}$ of the spore suspension was spread 
evenly on cooled PDA plates using a sterile spreading rod. Each control and treatment was performed in three replicates. Finally, the plates were incubated at $28^{\circ} \mathrm{C}$ for $2-3$ days after standing for 3-5 $\mathrm{min}$.

\subsubsection{Measurement of the Inhibition Zone}

The inhibition zone created near the agar well that was drilled into the PDA plate displayed the antifungal activity of silver nanoparticles. About $100 \mu \mathrm{L}$ of the spore suspension $\left(10^{6} \mathrm{~mL}^{-1}\right)$ was evenly smeared on a solid PDA plate. Five wells $(\varphi=8 \mathrm{~mm})$ were drilled by a hole puncher, and different volumes $(20,30,40$, and $50 \mu \mathrm{L})$ of nanosilver colloid and $50 \mu \mathrm{L}$ sterile water were dripped into corresponding agar well. After incubation for several days, an inhibition zone appeared near the agar well if the filling liquid had antifungal activity. The diameter of the inhibition zone varied as well. However, no inhibition zone was created near the well that contained sterile water. Each control and treatment was performed in three replicates. The plates were incubated at $28^{\circ} \mathrm{C}$ for $2-3$ days after standing for 3-5 min.

\section{Results and Discussion}

\subsection{Biosynthesis of Silver Nanoparticles}

Silver $\left(\mathrm{Ag}^{0}\right)$ was formed from $\mathrm{AgNO}_{3}\left(\mathrm{Ag}^{+}\right)$and plant extract. Figure 1 shows that the solution color changed from faint yellow to reddish-brown after adding $1 \mathrm{mmol} \cdot \mathrm{L}^{-1}$ $\mathrm{AgNO}_{3}$, indicating the formation of silver nanoparticles [21,22]. The maximum absorption peak appeared at $441 \mathrm{~nm}$, according to the surface plasmon resonance of silver nanoparticles [18]. Silver nanoparticles could be synthesized by physical, chemical, and biological methods. Among these methods, the last one is preferred by researchers owing to its unique virtues, such as the abundance of synthesis materials, easy operation, eco-friendly nature, and so forth [23-27]. Hence, the biosynthesis of silver nanoparticles by the microwaveassisted method has been the least time-consuming approach until now.
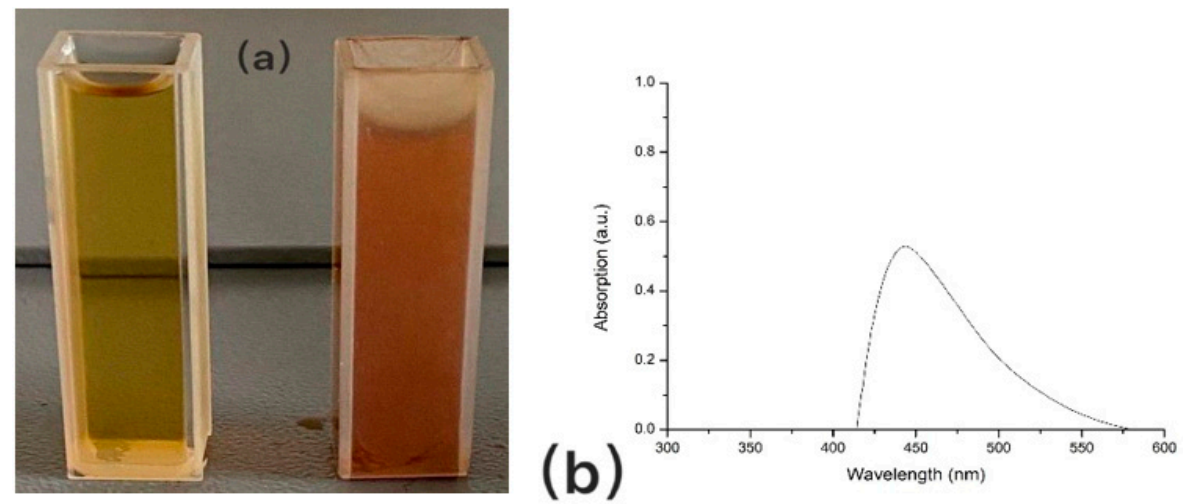

Figure 1. Biosynthesis of silver nanoparticles mediated by C. Canadensis. (a) Image of leaf extract without and with $\mathrm{AgNO}_{3}$, (b) UV-vis absorption spectrum of silver nanoparticles.

\subsection{TEM Analysis of Silver Nanoparticles}

Figure $2 \mathrm{a}-\mathrm{c}$ shows that silver nanoparticles synthesized from the $C$. canadensis leaf extract were primarily near-spherical, with rare aggregations. For definite particle size and size distribution, 200 particles were randomly selected for measurement using Image J software. The results showed that the biosynthesized silver nanoparticles were between 18.1 and $75.0 \mathrm{~nm}$, with an average size of $43.9 \mathrm{~nm}$ (Figure 2d).

\subsection{SEM Analysis of Silver Nanoparticles}

The whole morphology of silver nanoparticles was scanned using SEM. The images are shown in Figure 3a-c. The EDX graph in Figure 3d demonstrates the existence of silver, while the other signals, such as K, C, and O, may be attributed to the C. canadensis leaf extract on the substrate. 

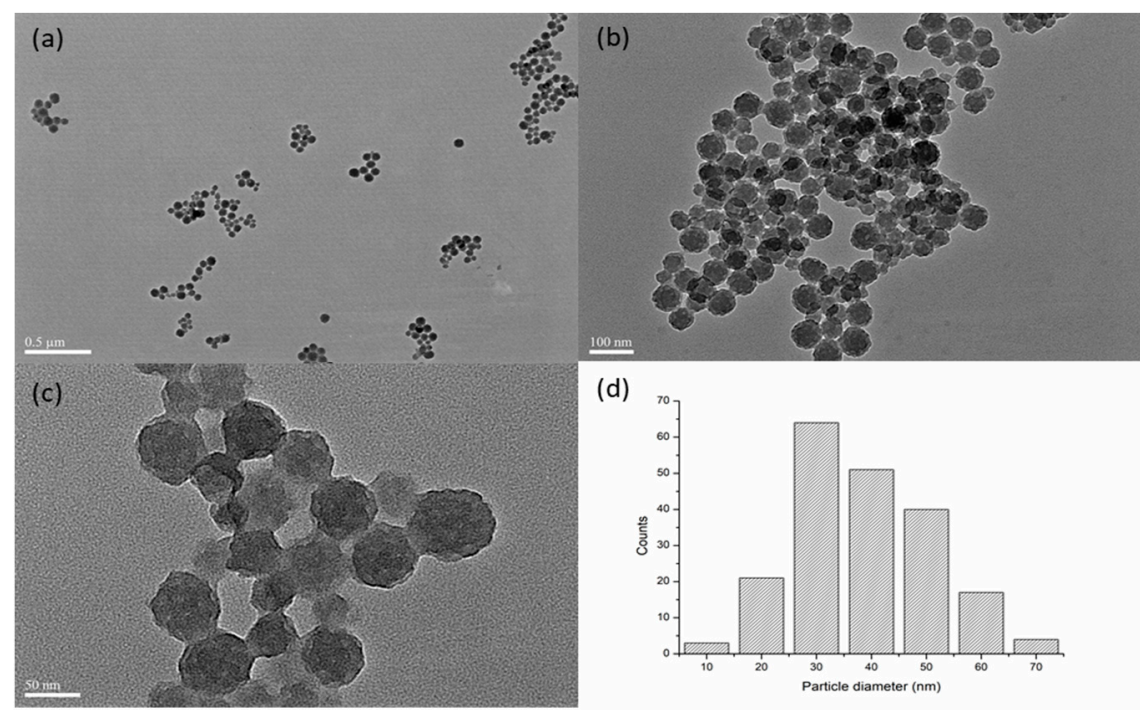

(d)

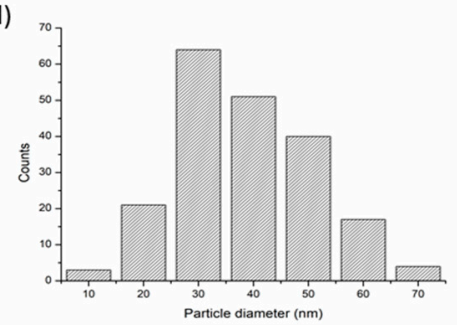

Figure 2. TEM images (a-c) and size distribution (d) of silver nanoparticles.

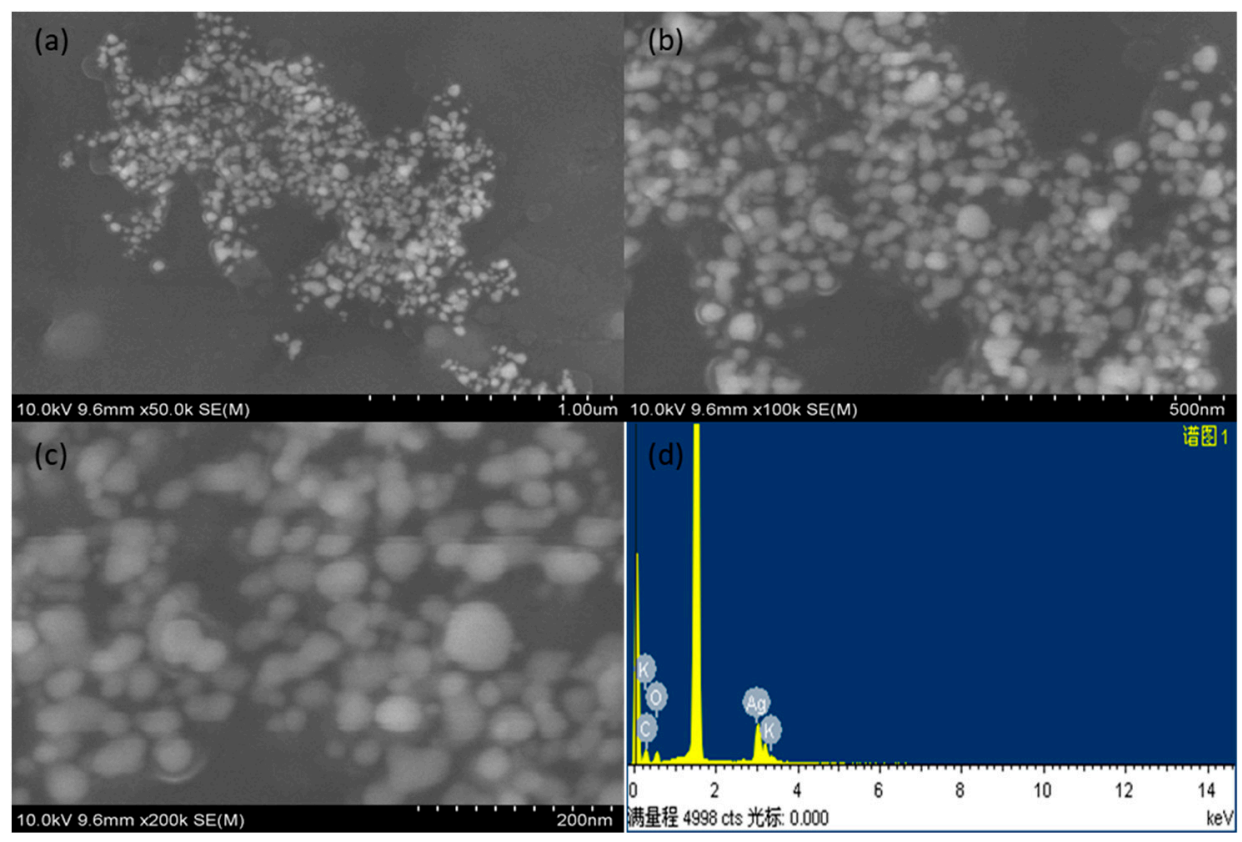

Figure 3. SEM images (a-c) and EDX spectrum (d) of silver nanoparticles.

\subsection{XRD Analysis of Silver Nanoparticles}

The XRD pattern of biosynthesized silver nanoparticles is shown in Figure 4. It demonstrates the existence of Ag with a monoclinic crystalline system. The reflections with $2 \theta$ values of $22.26^{\circ}, 26.52^{\circ}, 28.18^{\circ}, 30.88^{\circ}, 32.62^{\circ}, 36.80^{\circ}, 43.10^{\circ}, 44.80^{\circ}$, and $63.20^{\circ}$ observed on the spectrum should be indexed to silver faces of (111), (200), and (220) [28]; the $2 \theta$ value of $76.10^{\circ}$ might be related to (420) plane [29]. 


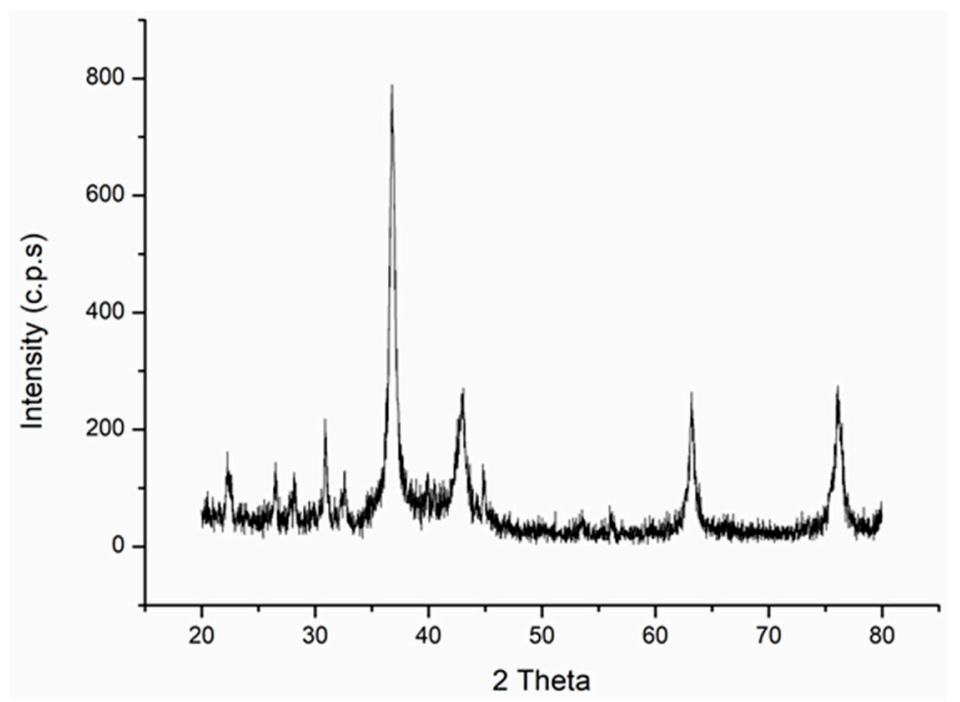

Figure 4. XRD pattern of silver nanoparticles.

\subsection{Inhibition of Colony Growth}

Figure 5 shows that various concentrations of silver nanoparticles exhibited prominent antifungal activity against the colonies of $B$. maydis. For the control, the colony diameter was $7.5 \mathrm{~cm}$, and it decreased dramatically as the concentration of silver nanoparticles increased. When the concentration of silver nanoparticles was $100 \mu \mathrm{L} \cdot \mathrm{mL}^{-1}$, the diameter reached its minimum value of $1.3 \mathrm{~cm}$, and the inhibition rate reached $88.6 \%$.

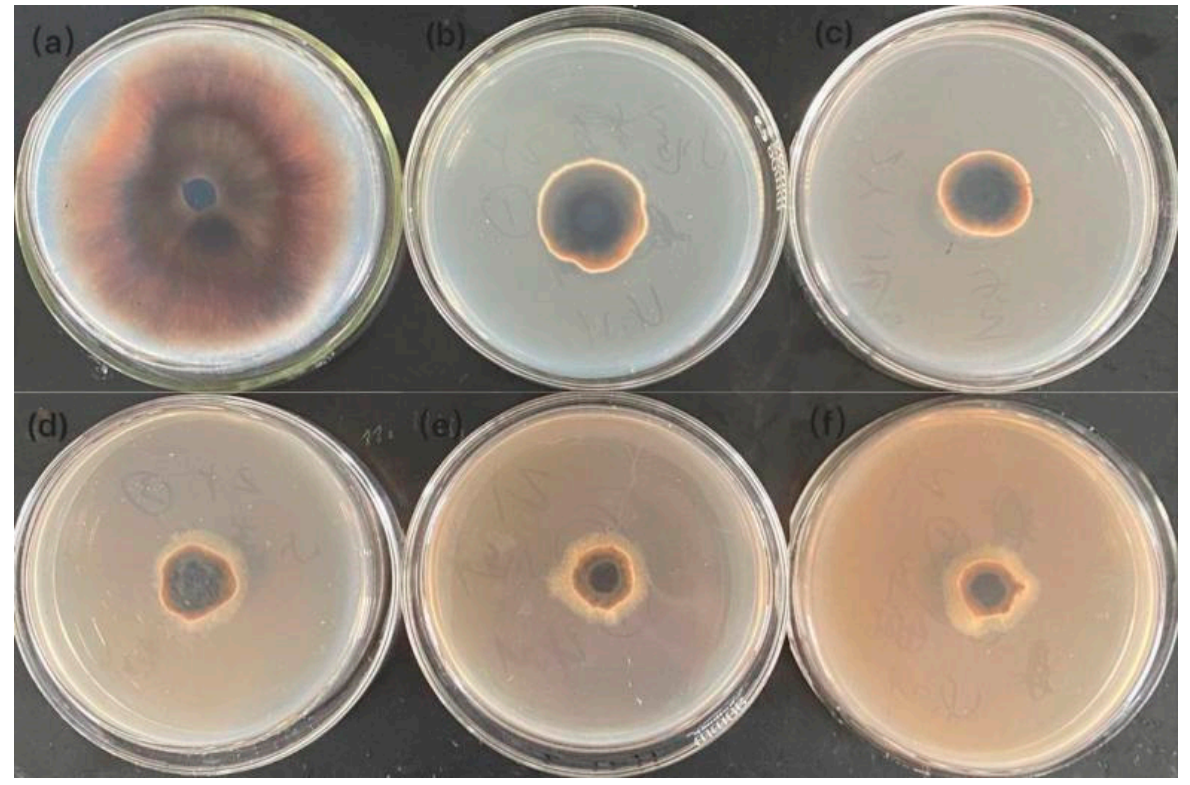

Figure 5. Inhibition of the colony growth of silver nanoparticles against B. maydis. (a) control isolate, (b-f) various concentration $\left(20,40,60,80\right.$, and $\left.100 \mu \mathrm{L} \cdot \mathrm{mL}^{-1}, v / v\right)$ of silver nanoparticles.

\subsection{Influence on Colony Formation}

Figure 6 shows that that colony of B. maydis was dramatically inhibited by silver nanoparticles. A mass of colonies appeared all over the control plate. When the concentration of silver nanoparticles increased from 20 to $100 \mu \mathrm{L} \cdot \mathrm{mL}^{-1}(v / v)$, no colony formation occurred for all the treatments. The excellent antimicrobial activity of silver nanoparticles, including antibacterial, antifungal, and antiviral activities, has been widely demonstrated $[19,20,30-34]$. In fact, not only do the same silver nanoparticles show a diverse inhibitory effect against various pathogens [35-37], but silver nanoparticles synthesized by different methods exhibited different inhibitory activity against the same pathogen $[16,17]$. 
Although several studies reported the antifungal effect of silver nanoparticles against phytopathogens, the effect against B. maydis has rarely been reported. The inhibition effect of silver nanoparticles could be influenced by several parameters, such as the concentration of $\mathrm{AgNO}_{3}, \mathrm{pH}$, quantities of synthesis materials, stabilizers, modified substances, and so forth.

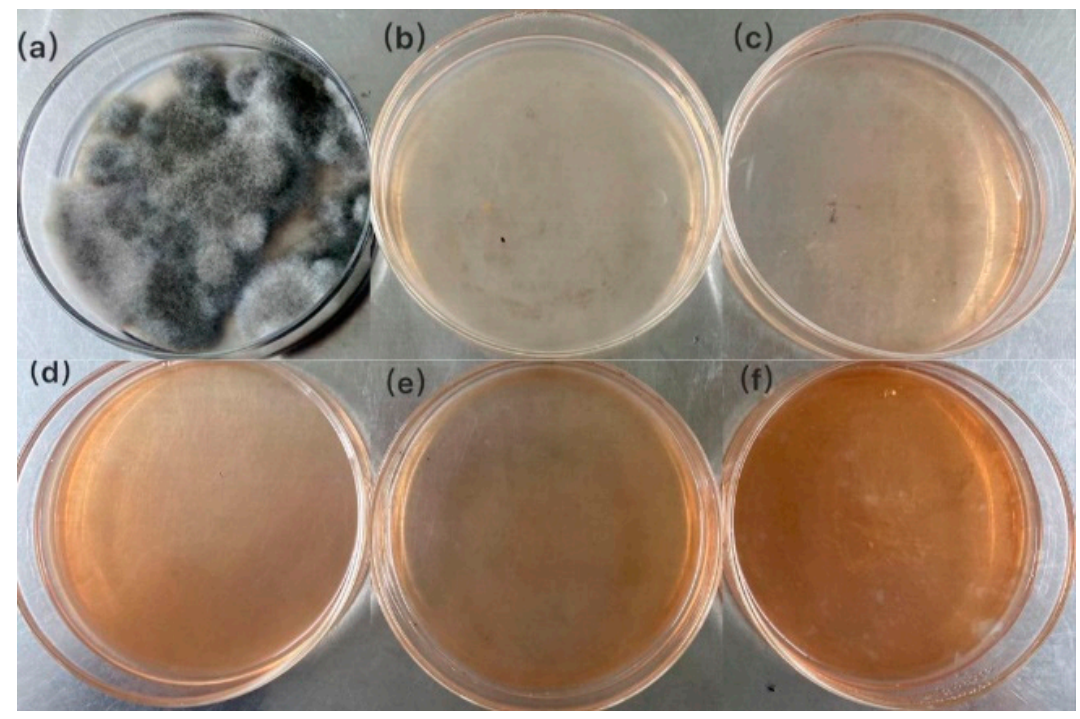

Figure 6. Colony formation of B. maydis on PDA plates. (a-f) different concentration $(0,20,40,60,80$, and $100 \mu \mathrm{L} \cdot \mathrm{mL}^{-1}, v / v$ ) of silver nanoparticles.

\subsection{Inhibition Zone Diameter}

The diameter of the inhibition zone also reflected the antimicrobial activity against fungus or bacteria. As shown in Table 1, the colony and mycelia of $B$. maydis covered the agar well without silver nanoparticles, with no inhibition zone. An obvious inhibition zone was created near the agar wells that contained different volumes of silver nanoparticles; it reached $13.20 \pm 1.12 \mathrm{~mm}$ when the well was filled with $50 \mu \mathrm{L}$ of silver nanoparticles. Besides the agar well diffusion approach used to measure the diameter of the inhibition zone, the paper disk diffusion method was also applied; the antimicrobial activity varied based on different nanomaterials, pathogens, and so forth [38,39].

Table 1. Diameter of inhibition zone of silver nanoparticles against B. maydis.

\begin{tabular}{cc}
\hline Volume of Silver Nanoparticles $(\boldsymbol{\mu L})$ & Inhibition Zone Diameter $(\mathbf{m m})$ \\
\hline 0 & $0.00 \pm 0.00$ \\
20 & $7.00 \pm 0.87$ \\
30 & $8.60 \pm 2.05$ \\
40 & $11.20 \pm 1.86$ \\
50 & $13.20 \pm 1.12$ \\
\hline
\end{tabular}

\section{Conclusions}

In this study, silver nanoparticles were biosynthesized from the C. Canadensis leaf extract using the microwave approach. Several analysis tools, such as UV-vis, TEM, SEM, $\mathrm{XRD}$, and EDX, were applied to characterize synthesized silver nanoparticles systematically. The antifungal activity of silver nanoparticles against $B$. maydis was tested through colony growth, colony formation, and inhibition zone. All the results demonstrated that the synthesized silver nanoparticles exhibited prominent antifungal activity against $B$. maydis. As is known to us, C. Canadensis plays two main roles: one is as a farmland weed that does great harm to agriculture, and the other is as Chinese herbal medicine that has an anti-inflammatory effect. This study developed the value of $C$. Canadensis, turning waste into treasure. The results also provide a novel approach and fungistat to control plant 
pathogens, and it contributes to reducing the dosage of chemical pesticides to alleviate agriculture problems, such as environmental pollution and drug residue.

Author Contributions: Conceptualization, W.H. and H.Y.; methodology, Y.Y. and X.C.; formal analysis, C.W. and K.Y.; investigation, Y.Y. and C.W.; writing-original draft preparation, Y.Y. and C.W.; writing — review and editing, W.H. and H.Y.; project administration, X.C. and K.Y. All authors have read and agreed to the published version of the manuscript.

Funding: This work was funded by the Key Research and Development Program of Anhui Province (202004a06020004), Natural Science Fund of Education Department of Anhui Province (KJ2018A0543, KJ2019A0814, KJ2019ZD57), Talent Introduction Project in Anhui Science and Technology University (NXYJ201602).

Institutional Review Board Statement: Not applicable.

Informed Consent Statement: Not applicable.

Data Availability Statement: Available on request.

Conflicts of Interest: The authors declare no conflict of interest.

\section{References}

1. Sun, S.W.; Xu, L.; Zou, Q.; Wang, G.H. BP4RNAseq: A babysitter package for retrospective and newly generated RNA-seq data analyses using both alignment-based and alignment-free quantification method. Bioinformatics 2020, 37, 1319-1321. [CrossRef] [PubMed]

2. Hou, C.; Yin, M.; Lan, P.; Wang, H.R.; Nie, H.; Ji, X.L. Recent progress in the research of Angelica sinensis (Oliv.) Diels polysaccharides: Extraction, purification, structure and bioactivities. Chem. Biol. Technol. Agric. 2021, 8, 13-26. [CrossRef]

3. Ji, X.L.; Cheng, Y.Q.; Tian, J.Y.; Zhang, S.Q.; Jing, Y.S.; Shi, M.M. Structural characterization of polysaccharide from jujube (Ziziphus jujuba Mill.) fruit. Chem. Biol. Technol. Agric. 2021, 8, 54-60. [CrossRef]

4. Osuwa, J.C.; Anusionwu, P.C. Some advances and prospects in nanotechnology: A review. Asian J. Inf. Technol. 2011, 10, 96-100. [CrossRef]

5. Khademhosseini, A.; Parak, W.J.; Weiss, P.S. Nanoscience and Nanotechnology around the World. ACS Nano 2016, 10, 4883-4884. [CrossRef]

6. Li, H.; Wang, F. Core-shell chitosan microsphere with antimicrobial and vascularized functions for promoting skin wound healing. Mater. Design 2021, 204, 109683. [CrossRef]

7. Zhao, L.; Wang, H.; Huo, K.; Cui, L.; Zhang, W.; Ni, H. Antibacterial nano-structured titania coating incorporated with silver nanoparticles. Biomaterials 2011, 32, 5706-5716. [CrossRef] [PubMed]

8. Ren, Y.Y.; Yang, H.; Wang, T.; Wang, C. Green synthesis and antimicrobial activity of monodisperse silver nanoparticles synthesized using Ginkgo biloba leaf extract. Phys. Lett. A 2016, 380, 3773-3777. [CrossRef]

9. Bakshi, M.; Singh, H.B.; Abhilash, P.C. The unseen impact of nanoparticles: More or less? Curr. Sci. 2014, 106, 350-352.

10. Kumari, A.; Guliani, A.; Singla, R.; Yadav, R.; Yadav, S.K. Silver nanoparticles synthesized using plant extracts show strong antibacterial activity. IET Nanobiotechnol. 2015, 9, 142-152. [CrossRef]

11. Huang, W.D.; Wang, C.J.; Duan, H.M.; Bi, Y.L.; Wu, D.G.; Du, J.L.; Yu, H.B. Synergistic Antifungal Effect of Biosynthesized Silver Nanoparticles Combined with Fungicides. Int. J. Agric. Biol. 2018, 20, 1225-1229.

12. Wang, C.; Kim, Y.J.; Singh, P.; Mathiyalagan, R.; Jin, Y.; Yang, D.C. Green synthesis of silver nanoparticles by Bacillus methylotrophicus, and their antimicrobial activity. Artif. Cell Nanomed. B 2016, 44, 1127-1132.

13. Huang, W.D.; Bao, Y.; Duan, H.M.; Bi, Y.L.; Yu, H.B. Antifungal effect of green synthesized silver nanoparticles against Setosphaeriaturcica. IET Nanobiotechnol. 2017, 11, 803-808. [CrossRef]

14. Ho, C.H.; Odermatt, E.K.; Berndt, I.; Tiller, J.C. Long-term active antimicrobial coatings for surgical sutures based on silver nanoparticles and hyper branched polylysine. J. Biomat. Sci.-Polym. E 2013, 24, 1589-1600. [CrossRef]

15. Li, W.R.; Xie, X.B.; Shi, Q.S.; Duan, S.S.; Ouyang, Y.S.; Chen, Y.B. Antibacterial effect of silver nanoparticles on Staphylococcus aureus. Biometals 2011, 24, 135-141. [CrossRef] [PubMed]

16. Khatami, M.; Mehnipor, R.; Poor, M.H.S.; Jouzani, G.S. Facile Biosynthesis of Silver Nanoparticles Using Descurainia sophia and Evaluation of Their Antibacterial and Antifungal Properties. J. Clust. Sci. 2016, 27, 1601-1612. [CrossRef]

17. Khatami, M.; Pourseyedi, S. Phoenix dactylifera (date palm) pit aqueous extract mediated novel route for synthesis high stable silver nanoparticles with high antifungal and antibacterial activity. IET Nanobiotechnol. 2015, 9, 184-190. [CrossRef]

18. Narayanan, K.B.; Park, H.H. Antifungal activity of silver nanoparticles synthesized using turnip leaf extract (Brassica rapa L.) against wood rotting pathogens. Eur. J. Plant. Pathol. 2014, 140, 185-192. [CrossRef]

19. Lu, L.; Sun, R.W.Y.; Chen, R.; Hui, C.K.; Ho, C.M.; Luk, J.M.; Lau, J.K.; Che, C.M. Silver nanoparticles inhibit hepatitis B virus replication. Antivir Ther. 2008, 13, 253-262. 
20. Lara, H.H.; Ayala-Nunez, N.V.; Ixtepan-Turrent, L.; Rodriguez-Padilla, C. Mode of antiviral action of silver nanoparticles against HIV-1. J. Nanobiotechnol. 2010, 8, 1-6. [CrossRef]

21. Khalil, N.M.; El-Ghany, M.N.A.; Rodríguez-Couto, S. Antifungal and anti-mycotoxin effificacy of biogenic silver nanoparticles produced by Fusarium chlamydosporum and Penicillium chrysogenum at non-cytotoxic doses. Chemosphere 2019, 218, 477-486. [CrossRef]

22. Huang, W.D.; Yan, M.H.; Duan, H.M.; Bi, Y.L.; Cheng, X.X.; Yu, H.B. Synergistic Antifungal Activity of Green Synthesized Silver Nanoparticles and Epoxiconazole against Setosphaeria turcica. J. Nanomater. 2020, 3, 1-7. [CrossRef]

23. Hussain, I.; Singh, N.B.; Singh, A.; Singh, H.; Singh, S.C. Green synthesis of nanoparticles and its potential application. Biotechnol. Lett. 2016, 38, 545-560. [CrossRef]

24. Albrecht, M.A.; Evan, C.W.; Raston, C.L. Green chemistry and the health implications of nanoparticles. Green Chem. 2006, 8, 417-432. [CrossRef]

25. Roy, S.; Das, T.K. Plant mediated green synthesis of silver nanoparticles-a review. Int. J. Plant Biol. Res. 2015, 3, $1044-1054$.

26. Mittal, A.K.; Chisti, Y.; Banerjee, U.C. Synthesis of metallic nanoparticles using plant extracts. Biotechnol. Adv. 2013, 31, 346-356. [CrossRef]

27. Song, J.Y.; Kim, B.S. Rapid biological synthesis of silver nanoparticles using plant leaf extracts. Bioproc. Biosyst. Eng. 2009, 32, 79-84. [CrossRef]

28. Sathiya, C.K.; Akilandeswari, S. Fabrication and characterization of silver nanoparticles using Delonixelata leaf broth. Spectrochim. Acta $A$ 2014, 128, 337-341. [CrossRef]

29. Philip, D. Green synthesis of gold and silver nanoparticles using Hibiscus rosasinensis. Physica E Low Dimens. Syst. Nanostruct. 2010, 42, 1417-1424. [CrossRef]

30. Elechiguerra, J.L.; Burt, J.L.; Morones, J.R. Interaction of silver nanoparticles with HIV-1. J. Nanobiotechnol. 2005, 3, 1-6. [CrossRef]

31. Rai, M.; Yadav, A.; Gade, A. Silver nanoparticles as a new generation of antimicrobials. Biotechnol. Adv. 2009, 27, 76-83. [CrossRef]

32. Nagajyothi, P.C.; Lee, K.D. Synthesis of plant-mediated silver nanoparticles using Dioscorea batatas rhizome extract and evaluation of their antimicrobial activities. J. Nanomater. 2011, 2011, 1-7. [CrossRef]

33. Kaviyaa, S.; Santhanalakshmia, J.; Viswanathanb, B.; Muthumaryc, J.; Srinivasanc, K. Biosynthesis of silver nanoparticles using Citrus sinensis peel extract and its antibacterial activity. Spectrochim. Acta A 2011, 79, 594-598. [CrossRef]

34. Khalil, M.M.H.; Ismail, E.H.; Baghdady, K.Z.E.; Mohamed, D. Green synthesis of silver nanoparticles using olive leaf extract and its antibacterial activity. Arab. J. Chem. 2014, 7, 1131-1139. [CrossRef]

35. Kathiraven, T.; Sundaramanickam, A.; Shanmugam, N.; Balasubramanian, T. Green synthesis of silver nanoparticles using marine algae Caulerpa racemosa and their antibacterial activity against some human pathogens. Appl. Nanosci. 2014, 5, 499-504. [CrossRef]

36. Waghmare, S.R.; Mulla, M.N.; Marathe, S.R.; Sonawane, K.D. Ecofriendly production of silver nanoparticles using Candida utilis and its mechanistic action against pathogenic microorganisms. Biotechnology 2015, 5, 33-38. [CrossRef]

37. Sarsar, V.; Selwal, M.K.; Selwal, K.K. Biogenic synthesis, optimisation and antibacterial efficacy of extracellular silver nanoparticles using novel fungal isolate Aspergillus fumigatus MA. IET Nanobiotechnol. 2016, 10, 215-221. [CrossRef]

38. Abboud, Y.; Saffaj, T.; Chagraoui, A.; El Bouari, A.; Brouzi, K.; Tanane, O.; Ihssane, B. Biosynthesis, characterization and antimicrobial activity of copper oxide nanoparticles (CONPs) produced using brown alga extract (Bifurcaria bifurcata). Appl. Nanosci. 2014, 4, 571-576. [CrossRef]

39. Khatami, M.; Heli, H.; Jahani, P.M. Copper/copper oxide nanoparticles synthesis using Stachys lavandulifolia and its antibacterial activity. IET Nanobiotechnol. 2017, 11, 709-713. [CrossRef] 